\title{
NURSE BEHAVIOR IN IMPLEMENTATION OF DIABETES MELLITUS EDUCATION BASED ON THEORY OF PLANNED BEHAVIOR
}

\author{
Nadia Rohmatul Laili*, Sulistiawati**, Ika Yuni Widyawati* \\ *Faculty of Nursing, Universitas Airlangga \\ **Faculty of Medicine, Universitas Airlangga \\ Email: nadiarohmatul28@gmail.com
}

\begin{abstract}
Introduction: Education is the important component in self-management of Diabetes mellitus patients. Nurse as one of the health care provider should take an active role in giving adequate education. The aim of this study was to analyze factors influencing nurse's behavior in implementation of Diabetes mellitus education based on the theory of planned behavior. Method: This study used cross-sectional design. Population in this study were all nurses in the medicinal public hall whose were assigned to give education toward patients in 62 public health center in Surabaya city in 2016. Sampling technique used total sampling and 112 nurses obtained as samples. Variables in this study consist of attitude, subjective norm, perceived behavioral control (PBC), intention and practice in DM education. Data collection was using questionnaire and observation sheet and also analyzed using Spearman rho with $\alpha 0,05$. Result: Statistical analysis result shows there is a significant relationship between attitudes, subjective norm, perceived behavioral control (PBC) toward intention with p-value of 0,022 ; 0,048; and 0,000 respectively and there is no significant relationship between intention and practice of Diabetes mellitus education with p-value 0,194. Nurse's attitudes, subjective norm, perceived behavioral control (PBC) had a positive effect toward intention of Diabetes mellitus education, but intention had no effect toward practice of Diabetes mellitus education in public health center. Conclusion: Theory of Planned Behavior (TPB) stated that individual behavior occurred because of intention that could be affected by attitude, subjective norm, and perceived behavioral control (PBC). The future study was expected to use a qualitative approach and related study regarding development of education media in public health center.
\end{abstract}

Keywords: Education, nurse, Diabetes mellitus, Theory of Planned Behavior

\section{INTRODUCTION}

Diabetes mellitus commonly referred to DM type 1 and DM type 2, is a chronic metabolic disease which requires complex patient involvement in management (Powers et al. 2015). Self-care for DM sufferer plays an important role in preventing and reducing complications, morbidity, and mortality of patients (Rahim-Williams 2011). One of the core components to improve the self-care of Diabetes mellitus is education (Formosa et al. 2012). Education is a basic tool which is crucial to maintain the metabolic control in DM effective care (Irons et al. 2007). Inadequate patient education is the most influential factor to the lack of knowledge and skills of self-care management of patients (Golchin 2008), which the former has an impact on the increased risk of complications and disruption of the economic aspects (Parvaneh \& Abazari 2012).

Surabaya, which is divided into five regions, has 62 community health centers (Public health center) with high number of diabetes sufferers visiting Public health center, based on the report of Health Department of Surabaya. The report shows those number in 2012, 2013 and 2014 as many as 21606, 16069 and 13513 people respectively. It indicates the rate of visitor for getting DM treatment declined sharply from 2012 to 2014. However, Surabaya is still at the top of the city with the highest DM case in East Java which reached twelve thousand cases per year, followed by Bangkalan, Malang, And Lamongan (Pranoto 2015).

In Indonesia, Education modules has been developed for public and people with diabetes by Health Department of Surabaya and PERKENI in which the former contains the guidelines to educate DM. Socialization for PERKENI consensus book has been done, but the implementation of these recommendations is $2-45 \%$ only. Based on reports from the International Diabetes Management Practice Study (IDMPS), there is only $36.1 \%$ of DM sufferer who obtained the education (Soewondo 2011). Nurses in primary care settings only organize diabetes education in general with the unstructured format in a short time even this is conducted with a variety of other chronic diseases (Onuoha \& Ezenwaka 2014).

Based on preliminary studies conducted by researchers at one of Public health center in Surabaya through observation, DM education implemented in Public health center only gave suggestion to restrict eating, take medication 
regularly, and control every month to check up. Moreover, educational materials given was same for all patients. Not only the same method for all sufferer but also educational process did not use any media so that there was no simulation. The sufferer's family also was not involved in that method. The nurse did not assess an evaluation of the education provided and did not observe the patient's ability to perform self-care. It represents that the nurses at Public health center have not provided education in accordance with the standards set in Indonesia referring to the Health Ministry and PERKENI.

There are causes of implementing education according to standards, such as the lack of preparation and plan of the organization or health service, interpersonal relationship is not effective, and lack of training program on DM (Santos \& Torres 2012), lack of knowledge about guidelines for education (Odili \& Eke 2010; Jansink et al. 2010; Santos \& Torres 2012), the educational ability of nurses (Jansink et al. 2010), and limited of time, so many activities have short visit. Facility for the implementation of education is also an obstacle of DM education.

Nurses as part of health workers are also required to have a general requirement to provide care and diabetes education, namely knowledge, attitudes, and skills (Rodrigues et al. 2009). Nurse has a key role with primary health care for type 2 in which nurses should help patients to understand the process disease during attack and possible complications so they can teach patients to be able to apply selfcare (Macdonalds et al. 2013), so it is necessary to do research related to the behavior of nurses in the application of DM education.

The theory that can be used in analyzing the behavior of nurses is the Theory of Planned Behavior. Theory of Planned Behavior (TPB). This theory has been proved to significantly predict the intention and improvement of behavior (Wahyuni 2012), applying hand hygiene (White et al. 2015), observing the behavior of nurses related to patient safety (Jayadi et al. 2013), treatment for SARS patients (Ko et al. 2004) and also doing counseling and prescription of emergency contraception (Hauselt 2007). Nevertheless, these studies have not explained the behavior of the nurses in application of DM education.

Several researches are also conducted by some nurses for inpatient which they have not applied yet. The study, focused on nurses in primary care or Public health center related to the behavior for application of education DM, needs to be done considering the important role of nurses as health care providers and $90 \%$ of type 2 provided by the Public health center (Widyahening \& Soewondo 2012; Barbara \& Bruce 2015). So, that can be relied upon in making the concept of the solution to address the needs of nurses in primary care or Public health center in order to implement diabetes education effectively and properly

\section{METHODS}

This research used observational analytical research with cross sectional approach. The population was all nurses at Public health center around Surabaya to provide education for patients in 62 Public health center in 2016. The sample of this research were all nurses at public health center to provide education for patients in 2016. The total amount of those populations and samples were 112 nurses. The sampling technique was total sampling. The independent variable were attitudes, subjective norms, and perceived behavioral controls. The dependent variables were the nurse's intentions and practice in the implementation of Diabetes mellitus education.

Attitude, subjective norm, perceived behavioral control (PBC), and the intention are measured by using a questionnaire while the practice of DM education is measured by using observation sheet when DM education applied by nurses. The questionnaire for data collection has been tested for validity and reliability and has been declared valid and reliable.

According to the public health center head, an educator role is the responsibility of the nurse in charge of the assessment and anamnesis of patients, so the researchers decided to make the nurse in charge of conducting studies and histories as respondent. Filling out the questionnaire is made after researchers conducted observations. The collected data is processed and analyzed. Normality test results indicates that the attitudes, subjective norms, and perceived behavioral control (PBC) normally distribute while intention and practice of distribution are abnormal thus bivariate analysis has been used by using Spearman correlation test with $\alpha 0.05$. 


\section{RESULTS}

The results of the study includes background factors, attitudes, subjective norms, perceived behavioral control (PBC), the intentions and nurses actions in implementing education Diabetes mellitus, the influence of main factors (attitudes, subjective norms, perceived behavioral control) to the intention and its effects to the nurse action or practice of applying education.

Table 1 illustrates the personal information and background of respondents which are divided to ages, gender, education, work experience, respondent's salary, religion, tribe, and Knowledge about DM.

Table 1. Personal information and background the study of Nurse Behavior in Implementation of Diabetes Mellitus Education Based on Theory of Planned Behavior in Public health center around Surabaya in 2016

\begin{tabular}{|c|c|c|}
\hline Respondent characteristic & $\mathrm{n}$ & $\%$ \\
\hline \multicolumn{3}{|l|}{ Age } \\
\hline 21-30 year-old & 26 & 23,2 \\
\hline $31-40$ year-old & 42 & 37,5 \\
\hline $41-50$ year-old & 34 & 30,4 \\
\hline$>50$ year-old & 10 & 8,9 \\
\hline \multicolumn{3}{|l|}{ Gender } \\
\hline Male & 36 & 32,1 \\
\hline Female & 76 & 67,9 \\
\hline \multicolumn{3}{|l|}{ Education } \\
\hline Sekolah Perawat Kesehatan & 4 & 3,6 \\
\hline Diploma of Nursing & 76 & 67,8 \\
\hline Bachelor of Nursing & 32 & 28,6 \\
\hline \multicolumn{3}{|l|}{ Work Experience } \\
\hline$<1$ year & 1 & 0,9 \\
\hline $1-5$ year & 28 & 25 \\
\hline $6-10$ year & 50 & 44,6 \\
\hline$>10$ year & 33 & 29,5 \\
\hline \multicolumn{3}{|l|}{ Salary } \\
\hline $1.000 .000-2.999 .900$ & 11 & 9,8 \\
\hline $3.000 .000-4.999 .900$ & 66 & 58,9 \\
\hline$>5.000 .000$ & 35 & 31,3 \\
\hline \multicolumn{3}{|l|}{ Religion } \\
\hline Islam & 100 & 89,2 \\
\hline Katholik & 3 & 2,7 \\
\hline Kristen Protestan & 7 & 6,3 \\
\hline Hindu & 2 & 1,8 \\
\hline \multicolumn{3}{|l|}{ Tribe } \\
\hline Jawa & 102 & 91,1 \\
\hline Madura & 7 & 6,2 \\
\hline Lain-lain & 3 & 2,7 \\
\hline \multicolumn{3}{|l|}{ Knowledge } \\
\hline Baik & 91 & 81,3 \\
\hline Cukup & 20 & 17,8 \\
\hline Kurang & 1 & 0,8 \\
\hline
\end{tabular}

The most participating category of respondents are 31-40 year-old for age, female for gender, diploma of nursing for education, 610 years for work experience, 3-5 million rupiahs for salary, moslem for religion, Javanese for tribe, and good understanding of knowledge about DM. 
Most of the respondent's attitudes during implementation of educational have majority in positive category with a percentage of $55.4 \%$, subjective norms in moderate category with a percentage of $74.1 \%$, Perceived behavioral control (PBC) in moderate category that is equal to $97.3 \%$ and the majority of respondents (52.7\%) have good intentions. Most respondents (96.4\%) included in the category are less action in DM education.

Statistical analysis using Spearman correlation with $\mathrm{p}$ value $=0.048(<0.05)$ means there is a significant relationship between subjective norms and intention in the implementation of Diabetes mellitus education. Spearman correlation at 0.187 states that direction is a positive correlation with weak correlation. Perceived behavioral control (PBC) and intention in the implementation of Diabetes mellitus education also had a significant correlation $(\mathrm{p}$-value $=0.000)$. Spearman correlation at 0.558 indicates the positive correlation direction with moderate correlation. However, there was no relationship between the intention with practice in the implementation of Diabetes mellitus education ( $\mathrm{p}$ value $=0.194$ ).

Table 2. Cross Tabulation between attitude and intention In Implementation of Diabetes Mellitus Education Based on Theory of Planned Behavior in Public health center around Surabaya in 2016

\begin{tabular}{|c|c|c|c|c|c|c|}
\hline \multirow{3}{*}{ Attitude } & \multicolumn{4}{|c|}{ Intention } & \multirow{2}{*}{\multicolumn{2}{|c|}{ Total }} \\
\hline & \multicolumn{2}{|c|}{ Good } & \multicolumn{2}{|c|}{ Less } & & \\
\hline & $\mathrm{n}$ & $\%$ & $\mathrm{n}$ & $\%$ & $\mathrm{n}$ & $\%$ \\
\hline Positive & 35 & 56,5 & 27 & 43,5 & 62 & 100 \\
\hline Negative & 24 & 48 & 26 & 52 & 50 & 100 \\
\hline Total & 59 & 52,7 & 53 & 47,3 & 112 & 100 \\
\hline
\end{tabular}

Table 3. Cross Tabulation between subjective norm and intention In Implementation of Diabetes Mellitus Education Based on Theory of Planned Behavior in Public health center around Surabaya in 2016

\begin{tabular}{|c|c|c|c|c|c|c|}
\hline \multirow{3}{*}{ Subjective Norm } & \multicolumn{4}{|c|}{ Intention } & \multirow{2}{*}{\multicolumn{2}{|c|}{ Total }} \\
\hline & \multicolumn{2}{|c|}{ Good } & \multicolumn{2}{|c|}{ Less } & & \\
\hline & $\mathrm{n}$ & $\%$ & $\mathrm{n}$ & $\%$ & $\mathrm{n}$ & $\%$ \\
\hline Good & 11 & 64,7 & 6 & 35,3 & 17 & 100 \\
\hline Moderate & 44 & 53 & 39 & 47 & 83 & 100 \\
\hline Less & 4 & 33,3 & 8 & 66,7 & 12 & 100 \\
\hline Total & 59 & 52,7 & 53 & 47,3 & 112 & 100 \\
\hline
\end{tabular}

Table 4. Cross Tabulation between perceived behavioral control (PBC) and intention In Implementation of Diabetes Mellitus Education Based on Theory of Planned Behavior in Public health center around Surabaya in 2016

\begin{tabular}{|c|c|c|c|c|c|c|}
\hline \multirow{3}{*}{$\begin{array}{c}\text { Perceived } \\
\text { Behavioral Control }\end{array}$} & \multicolumn{4}{|c|}{ Intention } & \multirow{2}{*}{\multicolumn{2}{|c|}{ Total }} \\
\hline & \multicolumn{2}{|c|}{ Good } & \multicolumn{2}{|c|}{ Less } & & \\
\hline & $\mathrm{n}$ & $\%$ & $\mathrm{n}$ & $\%$ & $\mathrm{n}$ & $\%$ \\
\hline Good & 1 & 100 & 0 & 0 & 1 & 100 \\
\hline Moderate & 58 & 53,2 & 51 & 46,8 & 109 & 100 \\
\hline Less & 0 & 0 & 2 & 100 & 2 & 100 \\
\hline Total & 59 & 52,7 & 53 & 47,3 & 112 & 100 \\
\hline
\end{tabular}


Table 5. Cross Tabulation between intention and practice In Implementation of Diabetes Mellitus Education Based on Theory of Planned Behavior in Public health center around Surabaya in 2016

\begin{tabular}{|c|c|c|c|c|c|c|}
\hline \multirow{3}{*}{ Intention } & \multicolumn{4}{|c|}{ Practice } & \multirow{2}{*}{\multicolumn{2}{|c|}{ Total }} \\
\hline & \multicolumn{2}{|c|}{ Good } & \multicolumn{2}{|c|}{ Less } & & \\
\hline & $\mathrm{n}$ & $\%$ & $\mathrm{n}$ & $\%$ & $\mathrm{n}$ & $\%$ \\
\hline Good & 3 & 5,1 & 56 & 94,9 & 59 & 100 \\
\hline Less & 1 & 1,9 & 52 & 98,1 & 53 & 100 \\
\hline Total & 4 & 3,6 & 108 & 96,4 & 112 & 100 \\
\hline \multicolumn{7}{|c|}{ Spearman correlation $\mathrm{p}=0,194$} \\
\hline
\end{tabular}

\section{DISCUSSION}

Statistical analysis showed a significant relationship between attitude and intention which means that the attitude of nurses about DM education affects their intention in implementing DM education. These results are consistent with research conducted by Kortteisto et al. (2010) which states that the attitude is an important factor associated with the intention of health workers for using clinical practice reference. Good intention tends to be influenced by the positive attitude of nurses. Ko et al. (2004) also proved that a positive attitude contributes significantly in predicting the intention of nurses to perform maintenance on SARS patients. This is in accordance with the Theory of Planned Behavior stating that attitudes toward the behavior are a determining factor for the formation of intentions (Ajzen 2005).

Attitude can affect a person intention to perform a behavior. An individual will intend to behave in certain ways when he/she vote positively. The attitude of nurses in the educational application of DM influenced by belief or conviction that a good and corresponding recommendation education DM will result in a good outcome for the patient. Nurses also believe that DM education will be able to help the patients to perform self-care management well.

Good intention tends to be influenced by a positive attitude, but there are respondents who have a positive attitude have less intention, and also respondents who have a negative attitude have good intentions. This could be caused by subjective norms and perceived behavioral control, and every individual. They have its perception of factors which is affecting their intentions. In some situations, one or two factors can be used to explain the intention, and most of these three factors play a role in explaining the intention. In addition, every individual has consideration to decide what the most influential individuals in behavior is (Ajzen 2005).

The statistical test result shows a significant relationship between subjective norms and intention. Intention nurse education in the application of DM is influenced by subjective norms (related parties) in implementing DM education at Public health center. These results are consistent with research conducted Kortteisto et. al. (2010) which states that the subjective norm is an important factor associated with health worker's intention to use clinical practice reference.

The results showed that most respondents had medium subjective norms for implementation of Diabetes mellitus education at Public health center. This may be caused by reference or party getting involved on individuals. The nurses would assume that the related parties did not show their hope to educate well and did not motivate nurses to educate as well as recommendations so that the nurses did not believe that other people or reference would approve or support their actions in implementing the education according to recommendations. Nurses did not have a subjective norm that put pressure on themselves to educate DM. For example, there was no written regulations in detail and binding set the nurse's responsibility of educating DM according to the recommendations, none of the patients or families who asked for education, no demands, motivation, and recognition from colleagues and other health professionals.

Good intention tends to be influenced by good subjective norms, but there are respondents who have a good subjective norms 
while they have less intention. This could be caused by the attitudes and perceived behavioral control. In addition, lack of motivation, demands, monitoring, and evaluation from third-parties, such as the Health Department Surabaya, Public health center head, colleagues, or even other health professionals, make nurses think that the related parties do not want them to apply DM education as recommendation and not a problem for nurses if they do not apply DM education. Therefore the nurses do not intend to educate DM based on recommendation.

Statistical analysis showed a significant relationship between perceived behavioral control (PBC) to the intention, which means the perceived behavioral control (PBC) affects to the intention of nurses in implementing Diabetes mellitus education at Public health center. The results are consistent with research conducted (Wahyuni 2012) which states there is significant influence between the PBC and intention of nurses behavior. This indicates that the better PBC on individual, the better his or her intention because PBC has a motivational effect to the intention.

The results showed that most respondents have perceived behavioral control (PBC) in medium category of Diabetes mellitus education at Public health center. Perceived behavioral control tends to produce good intentions.

Some respondents had a good PBC but their intention is less or more. According to (Azwar 2010) that in some situations, PBC is not realistic, as the condition when people faced the available resources changing or when a new element appears in that situation. Such conditions is clearly seen there are internship students of nursing at public health center that have certain competencies demands including anamnesis and educate the patient so that the nurses have to adjust the current conditions as supervising students and not directly involved in nursing care to patients. This is predicted when the PBC is not directly proportional with the intention possessed.

Statistical analysis showed that there is no significant relationship between intentions and actions in the implementation of Diabetes mellitus education, which means intention does not affect the actions of nurses. This research relates to another research Kortteisto (2010) which states that primary care has a negative effect on the variable intention characterized by low rate of primary care health workers to run standard operational procedure rather than hospital health workers.

The results of studies pointed out that there is no relationship between intentions and actions in implementing Diabetes mellitus education. This relates to Ajzen opinion (2005) that the accuracy intention in predicting the behavior is not certainly unconditional since it was found in some studies that intentions do not always produce that behavior. According to Ajzen (2005), although many experts who have shown a strong relationship between intention and behavior, the study sometime also found a weak correlation between both of them.

Azwar (2010) stated that according to the theory of planned behavior, among the various beliefs, the availability of opportunities and resources are the reason to determine intention and attitude. This belief can be derived from the experience, and also it can be influenced by indirect information about the behavior, for example by looking at the experience of a friend or someone else, it is also be influenced by several other factors that reduce or increase the effect the difficulty committing acts.

\section{CONCLUSION}

A positive attitude of nurses for implementation of diabetes mellitus education will lead good intentions in implementation of diabetes mellitus education. A good subjective norm will lead intentions in implementation of diabetes mellitus education. A good perceived behavioral control will lead to good intentions in the implementation of diabetes mellitus education. Intention has no effect on the action of diabetes mellitus education implementation at public health center.

It needs an association's standing for diabetes sufferer from every area or Public health center in order to facilitate nurses to accommodate the DM education program and also activities based on patient empowerment and community to help the role of health professionals in diabetes management.

Need to do research with a qualitative approach to understand and obtain the information deeper about the weakness pf implementing DM education. It needs to do research related to the development of media education at Public health center. 


\section{REFERENCES}

Ajzen, I., 2005. Attitudes, personality, and behavior 2nd ed., Berkshire: Open University Press.

Azwar, S., 2010. Sikap manusia teori dan pengukurannya 2nd ed., Yogyakarta: Pustaka Pelajar offset.

Barbara, D. \& Bruce, A., 2015. Management of diabetes by primary health care nurses in Auckland, New Zealand. JPrim Health Care, 7(1), pp.42-50.

Formosa, C., Gatt, A. \& Chockalingam, N., 2012. The importance of diabetes foot care education in primary care setting. Journal of Diabetes Nursing, 16(10), pp.410-414.

Golchin, M., 2008. Knowledge and practice on insulin self-injection procedure in diabetic patients at Qozvin diabetes unit. The journal of Qazvin Univ. of Med. Sci, 12(1), pp.8-11.

Hauselt, M., 2007. An application of the theory of planned behaviour on nurse mid wives' intentions to counsel and prescribe emergency contraception. University of Colorado.

Irons, B. et al., 2007. The need for a community diabetes education curriculum for healthcare professionals. Journal of continuing education in nursing, 38(5), pp.227-231. Available at: http://www.ncbi.nlm.nih.gov/pubmed/17 907667.

Jansink, R. et al., 2010. Primary care nurses struggle with lifestyle counseling in diabetes care: a qualitative analysis. $B M C$ family practice, 11(1), p.41. Available at: http://www.biomedcentral.com/14712296/11/41.

Jayadi, M. et al., 2013. Applying theory of planned behavior in predicting of patient safety behaviors of nurses. Materia socio-medica, 25(1), pp.52-58. Available at: http://www.pubmedcentral.nih.gov.

Ko, N. et al., 2004. Applying theory of planned behavior to predict nurses intention and volunteering to care for SARS patients in southern Taiwan. The Kaohsiung journal of medical sciences, 20(8), pp.389-398. Available at: http://www.kjmsonline.com.

Kortteisto, T., Kaila, M. \& Komulainen, J., 2010. Healthcare professionals' intentions to use clinical guidelines: A survey using the theory of planned behaviour. Implementation Science, $5(51)$.

Macdonalds, L. et al., 2013. Nurse-patient communication in primary care diabetes management: an exploratory study. $B M C$ nursing, 12(1), p.20.

Odili, V. \& Eke, I., 2010. Knowledge of diabetes mellitus among registered nurses in Benin City. International Journal of Health Research, 3(3), pp.145-151.

Onuoha, P. \& Ezenwaka, C., 2014. Diabetes patient need support to practise selfmonitoring of blood glucose levels. Asian journal od sciense and technology, 5(12), pp.789-792. Available at: http://www.journalajst.com.

Parvaneh \& Abazari, Z., 2012. Inadequate investment on management of diabetes education. Res med, 17(8), pp.792-798.

Powers, M. et al., 2015. Diabetes Selfmanagement Education and Support in Type 2 Diabetes: A Joint Position Statement of the American Diabetes Association, the American Association of Diabetes Educators, and the Academy of Nutrition and Dietetics. Diabetes Care, 38(13), pp.1-9. Available at: http://care.diabetesjournals.org.

Pranoto, A., 2015. Surabaya peringkat tertinggi diabetes. Harian Bhirawa, p.3. Available at: https://issuu.com/harianbhirawacetak.

Rahim-Williams, 2011. Beliefs, behaviors, and modifications of type 2 diabetes selfmanagement among African American women. Journal of the National Medical Association, 103(3), pp.203-215.

Rodrigues, F. et al., 2009. Knowledge and attitude: important components in diabetes education. Revista latinoamericana de enfermagem, 17(4), pp.468-473.

Santos, L. \& Torres, H., 2012. Educational practices in diabetes mellitus: understanding the skills of health professionals. Florianopolis, 21(8), pp.574-580.

Soewondo, P., 2011. Current practice in the management of type 2 diabetes in indonesia: results from the international diabetes management practices study (IDMPS). Journal of Indonesians Medical Association, 61(12), pp.474-81.

Wahyuni, E.D., 2012. Pengembangan perilaku 
Jurnal Ners Vol. 12 No. 1 April 2017: 19-26

perawat dalam pendokumentasian asuhan keperawatan berbasis theory of planned behavior. Universitas Airlangga.

White, K. et al., 2015. Using a theory of planned behaviour framework to explore hand hygiene beliefs at the "5 critical moments" among Australian hospital- based nurses. BMC health services research, 15(1), p.59.

Widyahening, I. \& Soewondo, P., 2012. Capacity for management of type 2 diabetes mellitus (T2 DM) in primary health centers in indonesia. $J$ Indon Med Assoc, 62(11), pp.439-443. 